\title{
Synthesis of Artemisinin-Estrogen Hybrids Highly Active against HCMV, P. falciparum, and Cervical and Breast Cancer
}

Tony Fröhlich, ${ }^{\dagger}$ Anita Kiss, ${ }^{\dagger}$ János Wölfling, ${ }^{\ddagger}$ Erzsébet Mernyák, ${ }^{\ddagger}$ Ágnes E. Kulmány, ${ }^{\S}$ Renáta Minorics, ${ }^{\S}$ István Zupkó, ${ }^{\varnothing}$ Maria Leidenberger," Oliver Friedrich," Barbara Kappes," Friedrich Hahn, ${ }^{\perp}$

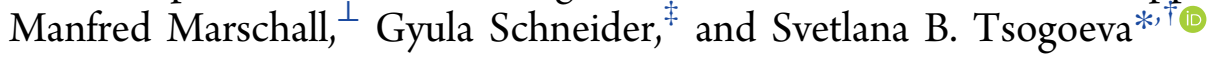

${ }^{\dagger}$ Organic Chemistry Chair I and Interdisciplinary Center for Molecular Materials (ICMM), Friedrich-Alexander University of Erlangen-Nürnberg, Nikolaus-Fiebiger-Straße 10, 91058 Erlangen, Germany

${ }^{\ddagger}$ Department of Organic Chemistry, University of Szeged, Dóm tér 8, H-6720 Szeged, Hungary

${ }^{\S}$ Department of Pharmacodynamics and Biopharmacy, University of Szeged, Eötvös u. 6, H-6720 Szeged, Hungary

"Institute of Medical Biotechnology, Friedrich-Alexander University of Erlangen-Nürnberg, Paul-Gordon-Straße 3, 91052 Erlangen, Germany

${ }^{\perp}$ Institute for Clinical and Molecular Virology, Friedrich-Alexander University of Erlangen-Nürnberg, Schlossgarten 4, 91054 Erlangen, Germany

\section{Supporting Information}

ABSTRACT: Artemisinin-estrogen hybrids were for the first time both synthesized and investigated for their in vitro biological activity against malaria parasites (Plasmodium falciparum 3D7), human cytomegalovirus (HCMV), and a panel of human malignant cells of gynecological origin containing breast (MCF7, MDA-MB231, MDA-MB-361, T47D) and cervical tumor cell lines (HeLa, SiHa, C33A). In terms of antimalarial efficacy, hybrid $8\left(\mathrm{EC}_{50}=3.8 \mathrm{nM}\right)$ was about two times more active than its parent compound artesunic acid $(7)\left(\mathrm{EC}_{50}=8.9 \mathrm{nM}\right)$ as well as the standard drug chloroquine $\left(\mathrm{EC}_{50}=9.8 \mathrm{nM}\right)$ and was, therefore, comparable to the clinically used dihydroartemisinin $(6)\left(\mathrm{EC}_{50}=2.4 \mathrm{nM}\right)$. Furthermore, hybrids 9-12 showed a strong antiviral effect with $\mathrm{EC}_{50}$ values in the submicromolar range $(0.22-$ $0.38 \mu \mathrm{M}$ ) and thus possess profoundly stronger anti-HCMV activity (approximately factor 25) than the parent compound artesunic acid (7) $\left(\mathrm{EC}_{50}=5.41 \mu \mathrm{M}\right)$. These compounds also exerted a higher in vitro anti-HCMV efficacy than ganciclovir used as the standard of current antiviral treatment. In addition, hybrids 8-12 elicited

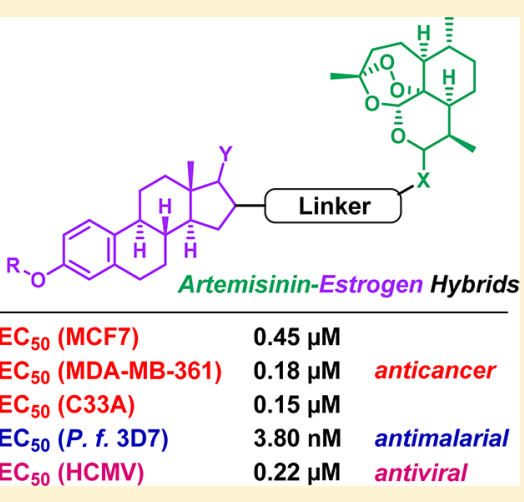
substantially more pronounced growth inhibiting action on all cancer cell lines than their parent compounds and the reference drug cisplatin. The most potent agent, hybrid 12, exhibited submicromolar $\mathrm{EC}_{50}$ values $(0.15-0.93 \mu \mathrm{M})$ against breast cancer and C33A cell lines.

KEYWORDS: Artemisinin, estrogen, antimalarial activity, anticancer activity, antiviral activity

$\mathrm{O}$ ver the last three decades, steroids have become a prime focus of research in the field of medicinal chemistry due to their remarkable and diverse pharmacological properties, such as anticancer, ${ }^{1,2}$ anti-inflammatory, ${ }^{3,4}$ antiparasitic, ${ }^{5}$ and antiviral activities. ${ }^{6,7}$ In particular, the two steroid hormones estrone (1) and $17 \beta$-estradiol (2) (Figure 1) attracted a lot of attention, as these two estrogens are known to be involved in the development of various cancer types such as breast, colorectal, prostate, and ovarian cancer. ${ }^{8}$ This led to the discovery of many different estradiol derivatives, which revealed to possess promising anticancer activity. In 2003, fulvestrant (3), an estrogen receptor antagonist, was approved in the USA for the treatment of hormone-related breast cancer, and since then it has been used in clinics. ${ }^{9}$ 2-Methoxyestradiol (4), an endogenous metabolite of $17 \beta$-estradiol (2), turned out to effectively inhibit cancer cell proliferation both in vitro and in vivo and is currently investigated in advanced phases of clinical trials. ${ }^{10-15}$ One of the main advantages of 2-methoxyestradiol (4) over other biologically active estrogens is that it does not act as an estrogen receptor agonist and consequently is free of the typical hormone-related side effects. ${ }^{16,17}$ Furthermore, no serious toxicity was observed in clinical trials when 2-methoxyestradiol (4) was applied in pharmacological effective doses, and therefore, it can be regarded as a promising anticancer agent. ${ }^{16,18}$

As of now, no artemisinin-estrogen hybrids were reported in the literature, and our working group already could obtain remarkable results applying the hybridization concept; ${ }^{19-22}$ where two different biologically active substances are linked via a covalent bond, ${ }^{23,24}$ we planned to use estrogen derivatives as

Received: August 17, 2018

Accepted: October 19, 2018

Published: October 19, 2018 


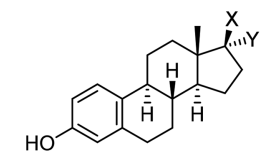

$1: X / Y=$ w/S

2: $\mathrm{X}=\mathrm{OH}, \mathrm{Y}=\mathrm{H}$

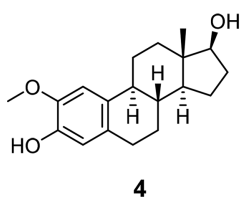

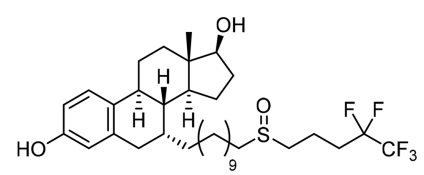

3

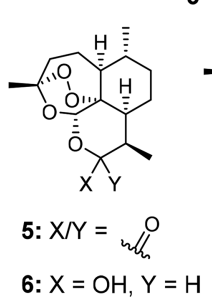

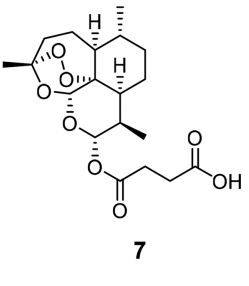

Figure 1. Structures of estrone (1), $17 \beta$-estradiol (2), fulvestrant (3), 2 methoxyestradiol (4), artemisinin (5), dihydroartemisinin (6), and artesunic acid (7).

precursors for the synthesis of novel artemisinin hybrid molecules. Since its isolation in 1972 from the plant Artemisia annua L. by Youyou Tu, for which she received the Nobel Prize in 2015, artemisinin (5) was intensively investigated for its pharmacological activities. ${ }^{25,26}$ Artemisinin (5) exhibits not only antimalarial activity, for what it was mainly used in traditional Chinese medicine for several centuries, ${ }^{27-29}$ but it also revealed to possess antiviral ${ }^{30-33}$ and anticancer efficacy. ${ }^{34-38}$ These promising properties are also reflected in its semisynthetic derivatives dihydroartemisinin $(6)^{39-41}$ and artesunic acid (7), ${ }^{42-45}$ bearing an alcohol or a carboxylic acid functionality and for that reason appear to be well-suited for hybridization purposes. Recently, it could be even demonstrated in a phase I clinical trial, which was performed in patients with metastatic breast cancer, that higher cumulative doses of artesunic acid are safe and well tolerated. ${ }^{46}$

Herein, we present the synthesis of five novel artemisininestrogen hybrids 8-12 (Figure 2) and the evaluation of their in vitro biological activity against malaria parasites (Plasmodium falciparum 3D7), human cytomegalovirus (HCMV), and a selection of human breast cancer cell lines (MCF7, MDA-MB231, MDA-MB-361, T47D) and cervical tumor cell lines (HeLa, $\mathrm{SiHa}, \mathrm{C} 33 \mathrm{~A})$.

Results and Discussion. Chemistry. Hybrids $\mathbf{8}$ and $\mathbf{9}$ were prepared in moderate to good yields $(81 \% / 45 \%)$ by standard amide coupling between estradiol amine 13 and either artesunic acid (7) or artemisinin-derived carboxylic acid $\mathbf{1 5}$ (Scheme 1). The reaction was conducted at room temperature overnight in a 1:1 mixture of $\mathrm{CH}_{3} \mathrm{CN}$ and $\mathrm{CH}_{2} \mathrm{Cl}_{2}$ as solvent, and $\mathrm{EDCI}$ was solely used as coupling agent. Surprisingly, under these conditions no ester formation was observed as a side reaction, and the desired amides $(\mathbf{8}, \mathbf{9})$ were the only products. The synthesis of the artemisinin-derived acid $\mathbf{1 5}$ was carried out in accordance to an already published protocol starting from dihydroartemisinin (6) (Scheme 2). ${ }^{47}$ The special feature of this artemisinin derivative is that it is free of the $\mathrm{O}$ atom at $\mathrm{C}-10$, and for that reason, it has been referred to a so-called C-10 nonacetal in the previous literature. This derivative has been considered to be more stable compared to the classical C-10-acetals such as artesunic acid (7). ${ }^{48}$ The other precursor, necessary for the synthesis of hybrids 8 and 9, 3-methoxy-estradiol-derived amine 13 (Scheme 2), was also prepared in analogy to procedures described in the literature. ${ }^{49-51}$ The stereoselectivity of the metal borohydride-mediated reduction of $16 \alpha$-azido estrone 3-methyl ether (17) toward $17 \alpha$ - and $17 \beta$-estradiol derivatives $18 \mathbf{a} / \mathbf{b}$ can be achieved by selecting different alkali metals ( $\mathrm{Li}, \mathrm{Na}$, or $\mathrm{K}$ ) as countercation. If bigger countercations like potassium are used, the $17 \beta$-isomer is predominantly formed (57\% yield), whereas smaller countercations such as lithium lead almost exclusively to the formation of the $17 \alpha$-isomer (59\% yield). $16 \alpha$-Azido $17 \beta$ estradiol 3-methyl ether $(\mathbf{1 8 b})$ was then converted to the desired amine 13 by hydrazine monohydrate mediated reduction catalyzed by Raney-Ni (95\% yield). The synthesis of hybrid $\mathbf{1 0}$ containing a 1,2,3-triazole linkage was realized by a coppercatalyzed 1,3-dipolar cycloaddition between $16 \alpha$-azido estrone 3-methyl ether (17) and artemisinin-derived alkyne 16, which afforded the desired product in $42 \%$ yield. Catalytic amounts of copper(II) sulfate and sodium ascorbate served as a source for copper(I), which was generated in situ. Alkyne 16 was prepared according to the literature by etherification of dihydroartemisinin (6) with propargyl alcohol. ${ }^{52}$ As a final step, 3-benzyloxy-17 $\beta$ hydroxy-16 $\beta$-hydroxymethyl-estrone derivative 14 was reacted with either artesunic acid (7) or artemisinin-derived acid $\mathbf{1 5}$ in a Steglich esterification in order to yield the desired hybrids 11 and 12 in 95/56\%. DCC and DMAP were used as coupling agents and $\mathrm{CH}_{2} \mathrm{Cl}_{2}$ as solvent. The ester formation took place only at the primary alcohol group, which is probably attributed to its higher reactivity and less steric hindrance. The stability of target

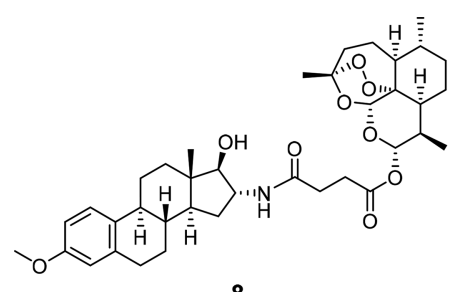

8

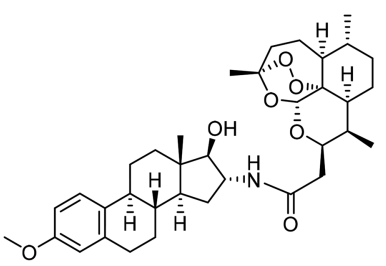

9

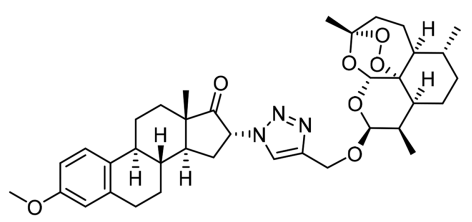

10<smiles></smiles>

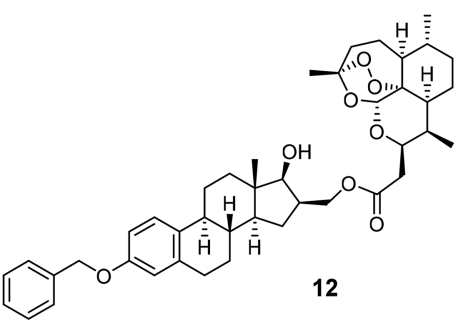

Figure 2. Novel hybrids 8-12 applied for biological tests against P. falciparum 3D7, HCMV, and breast and cervical cancer. 


\section{Scheme 1. Synthesis Route for Hybrids 8-12}

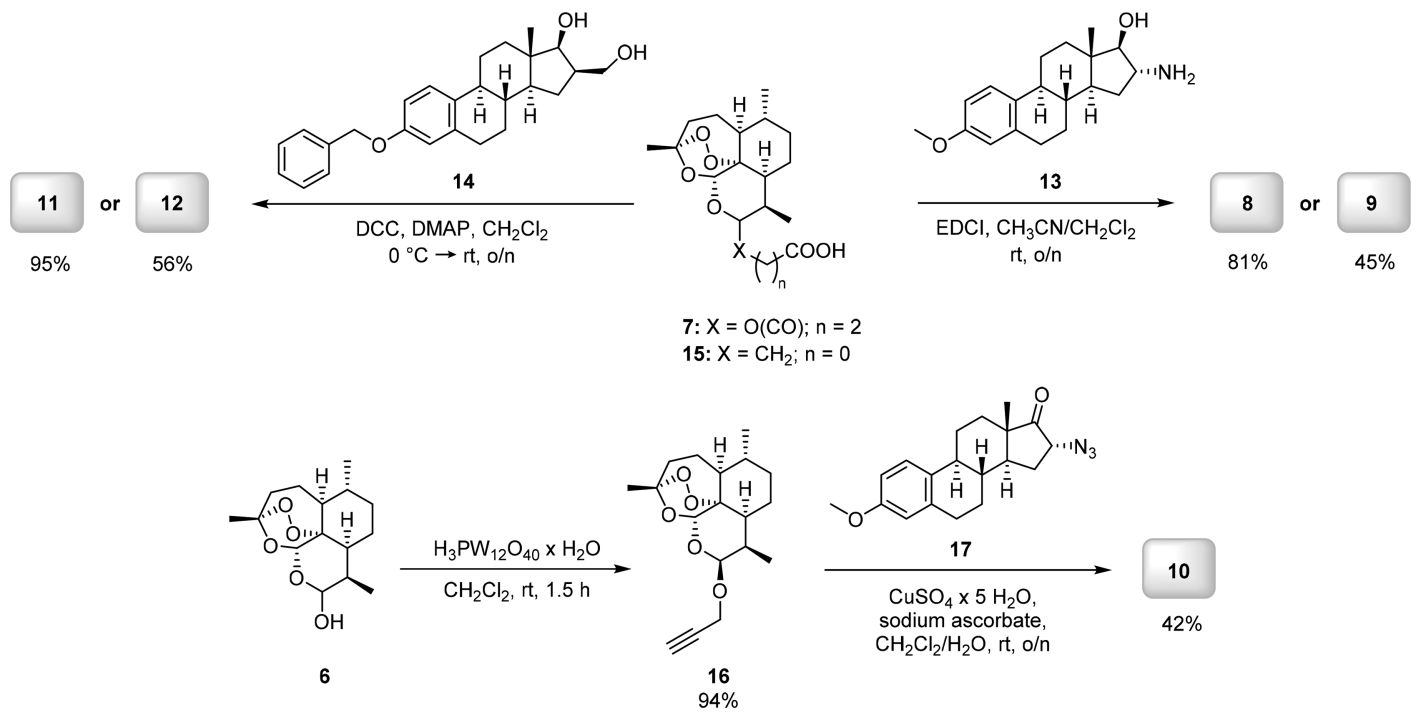

Scheme 2. Synthesis of Estrogen Precursor 13 and Artemisinin-Derived Acid 15

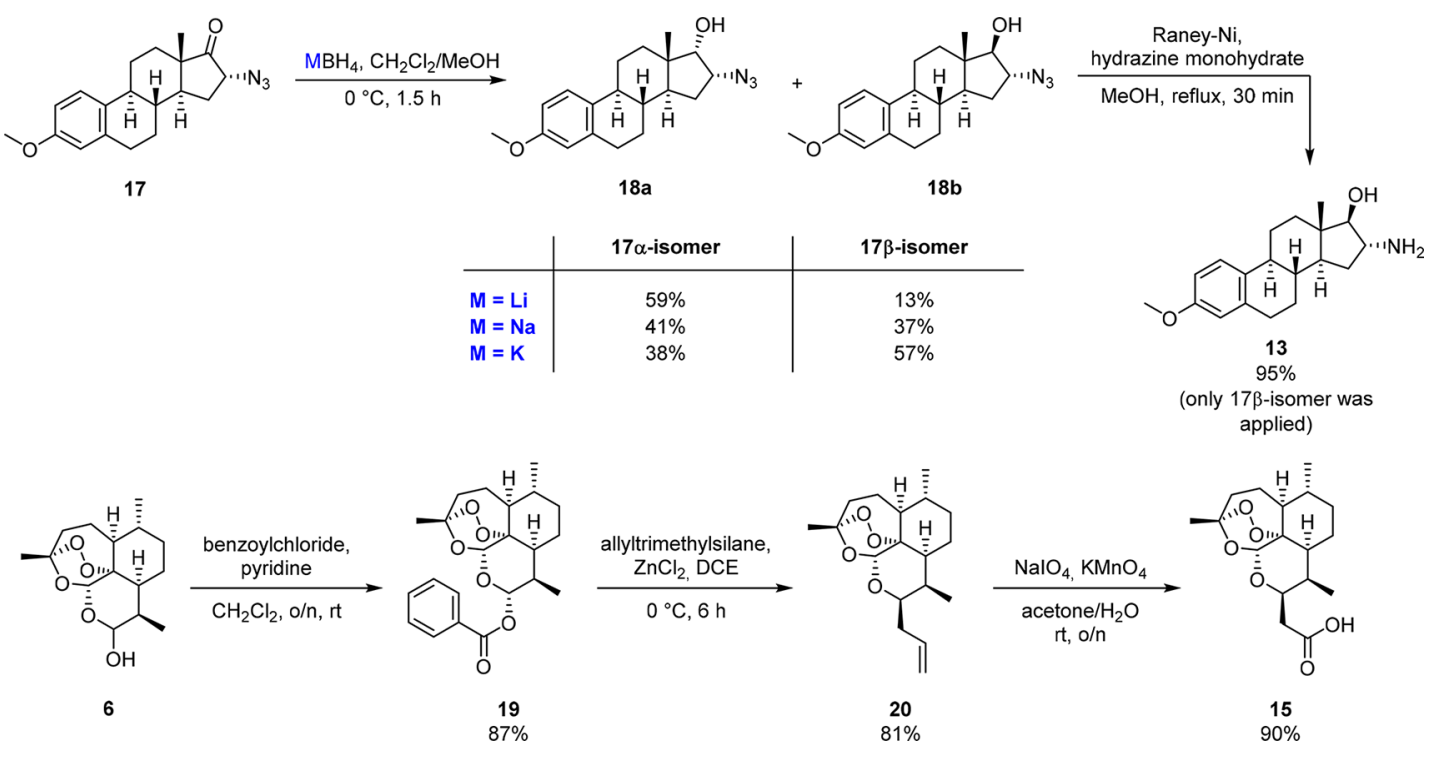

compounds 8-12 was examined by heat exposure at $65^{\circ} \mathrm{C}$ for 24 $\mathrm{h}$ or $40^{\circ} \mathrm{C}$ for $48 \mathrm{~h}$, respectively. After applying these conditions, ${ }^{1} \mathrm{H}$ NMR spectroscopy revealed that all synthesized hybrids remained sufficiently stable, i.e., less than $5 \%$ decomposition was detected in the recorded spectra.

The hydroxy group at C-3 of all artemisinin-estrogen hybrids 8-12 was protected via an ether group (benzyloxy or methoxy) to decrease the binding affinities of these novel compounds to the estrogen receptors and consequently reduce eventual hormonerelated side effects.

Biological Activity of the Hybrids. Antimalarial Activity. All synthesized hybrids $\mathbf{8 - 1 2}$ as well as their precursors, dihydroartemisinin (6), artesunic acid (7), estrone diol 14, and estrone azide 17 were investigated for their antimalarial activity against chloroquine-sensitive Plasmodium falciparum 3D7 parasites (Table 1). Hybrids 8-12 exhibited excellent to moderate antimalarial efficacy with $\mathrm{EC}_{50}$ values ranging from 3.8 to 128.8 $\mathrm{nM}$, while their estrogen precursors 14 and 17 showed no activity $\left(\mathrm{EC}_{50}>16,000 \mathrm{nM}\right)$. The best performing hybrid 8 was roughly two times more active than its parent compound artesunic acid
(7) $\left(\mathrm{EC}_{50}=8.9 \mathrm{nM}\right)$ as well as the standard drug chloroquine $(9.8 \mathrm{nM})$ and was therefore in terms of antimalarial efficacy comparable to the clinically used dihydroartemisinin $(6)\left(\mathrm{EC}_{50}=\right.$ $2.4 \mathrm{nM})$. Hybrids 9 and 12 containing a C-10 nonacetal artemisinin moiety were found to be two and four times, correspondingly, less active $\left(\mathrm{EC}_{50}\right.$ values of 7.7 and $128.8 \mathrm{nM}$ ) than their $\mathrm{C}-10$ acetal counterparts $\left(\mathrm{EC}_{50}(8)=3.8 \mathrm{nM}\right.$; $\left.\mathrm{EC}_{50}(11)=34.2 \mathrm{nM}\right)$. The same behavior was also observed in connection with artemisinin-quinazoline hybrids, ${ }^{53}$ which is in contrast to that of artemisinin-derived dimers. ${ }^{54}$ This indicates that different mechanisms might be involved for artemisininderived hybrids than for artemisinin-based dimeric structures. In addition, these $\mathrm{EC}_{50}$ values also demonstrate that a benzyloxy subunit at C-3 of the estrogen moiety (hybrids 11 and 12) seems to be unbeneficial for antimalarial activity of artemisinin-estrogen hybrids, as compounds $\mathbf{8}$ and $\mathbf{9}$ with a methoxy group were much more active. This result might be explained by the fact that hybrids 11 and $\mathbf{1 2}$ are more lipophilic than compounds 8 and $\mathbf{9 ,}$ and as a result, their cellular uptake into compartments of the 
Table 1. $\mathrm{EC}_{50}$ Values for Hybrids 8-12 and Selected Reference Compounds Tested against P. falciparum 3D7 Parasites, HCMV, and Various Human Breast and Cervical Cancer Cell Lines

\begin{tabular}{|c|c|c|c|c|c|c|c|c|c|c|}
\hline \multirow[b]{2}{*}{ compound } & \multirow[b]{2}{*}{ MW (g/mol) } & \multirow[b]{2}{*}{$\mathrm{EC}_{50}(\mathrm{nM})$ P.f. $3 \mathrm{D} 7$} & \multirow[b]{2}{*}{$\mathrm{EC}_{50}(\mu \mathrm{M}) \mathrm{HCMV}$} & \multicolumn{7}{|c|}{$\mathrm{EC}_{50}(\mu \mathrm{M})^{e}$} \\
\hline & & & & MCF7 & MDA-MB-231 & MDA-MB-361 & T47D & HeLa & $\mathrm{SiHa}$ & C33A \\
\hline chloroquine & 319.87 & $9.8 \pm 2.8^{a}$ & & & & & & & & \\
\hline ganciclovir & 579.98 & & $2.60 \pm 0.50^{b}$ & & & & & & & \\
\hline cisplatin & 300.05 & & & 5.78 & 19.13 & 3.76 & 9.78 & 12.43 & 7.87 & 3.69 \\
\hline $\operatorname{artemisinin}(5)$ & 282.14 & & $>10^{c}$ & - & - & - & - & - & - & - \\
\hline DHA (6) & 284.35 & $2.4 \pm 0.4^{a}$ & $>10^{c}$ & 8.24 & 10.69 & 1.71 & 4.60 & 10.46 & 29.80 & 1.71 \\
\hline artesunic acid (7) & 384.42 & $8.9 \pm 1.9$ & $5.41 \pm 0.60^{d}$ & 4.21 & 10.04 & 2.27 & 2.22 & 12.03 & $>30$ & 1.83 \\
\hline estrone amine 13 & 301.43 & - & - & 11.90 & 15.95 & 4.58 & 5.56 & 13.30 & 17.35 & 13.25 \\
\hline estrone diol 14 & 392.54 & $17,250 \pm 586$ & - & 12.89 & 12.75 & 2.77 & 8.32 & 12.80 & 7.75 & 12.20 \\
\hline estrone azide 17 & 325.41 & $>50,000$ & - & $>30$ & $>30$ & $>30$ & $>30$ & $>30$ & $>30$ & $>30$ \\
\hline 8 & 667.84 & $3.8 \pm 0.8$ & $2.44 \pm 0.13$ & 4.69 & 6.89 & 0.64 & 0.74 & 11.45 & 26.00 & 0.87 \\
\hline 9 & 609.80 & $7.7 \pm 2.4$ & $0.23 \pm 0.20$ & 1.02 & 1.85 & 0.69 & 1.17 & 1.65 & 6.21 & 0.57 \\
\hline 10 & 647.81 & $13.1 \pm 1.8$ & $0.24 \pm 0.01$ & 1.77 & 1.78 & 0.17 & 0.16 & 15.40 & 28.90 & 2.05 \\
\hline 11 & 758.95 & $34.2 \pm 3.2$ & $0.38 \pm 0.10$ & 0.76 & 2.30 & 0.20 & 0.22 & $>30$ & 28.43 & 1.73 \\
\hline 12 & 700.91 & $128.8 \pm 13.0$ & $0.22 \pm 0.00$ & 0.45 & 0.86 & 0.18 & 0.93 & 14.22 & 16.12 & 0.15 \\
\hline
\end{tabular}

malaria parasite in which they unfold their effect may be more limited.

Anticytomegaloviral Activity. Furthermore, hybrids 8-12 were analyzed for their antiviral activity, focusing on human cytomegalovirus (recombinant HCMV AD169-GFP) used for the infection of cultured primary human foreskin fibroblasts (HFFs). Experimental determination of $\mathrm{EC}_{50}$ values was carried out in accordance to a previously established protocol, ${ }^{55-58}$ and the results thereof are summarized in Table 1. Hybrids 9-12 exerted a high antiviral efficacy with $\mathrm{EC}_{50}$ values in the submicromolar range $(0.22-0.38 \mu \mathrm{M})$ and thus possessed a profoundly stronger anti-HCMV activity (approximately factor 25) than the parent compound artesunic acid (7). These compounds were also more effective than ganciclovir used as the gold standard of current antiviral treatment. In contrast to the determined antimalarial activities, C-10 nonacetal-linked artemisinin-derived hybrids $\mathbf{9}$ and $\mathbf{1 2}$ were more potent in antiHCMV activity than their C-10 acetal-linked counterparts (hybrids 8 and 11). This difference was most pronounced between compounds 8 and 9 . In this case, hybrid $8\left(\mathrm{EC}_{50}=2.44\right.$ $\mu \mathrm{M})$ was approximately ten times less active than hybrid $9\left(\mathrm{EC}_{50}\right.$ $=0.23 \mu \mathrm{M})$. Cell morphology, growth behavior, and signs of cytotoxicity were routinely monitored by microscopic inspection under compound treatment along the period of infection ( 7 days, referring to a situation of multiround viral replication), and no cytotoxicity was observed within the range of all concentrations tested.

Anticancer Activity. In a next step, hybrids 8-12 as well as their artemisinin and estrone precursors were investigated for their anticancer potential by means of MTT assay against a panel of human breast (MCF7, MDA-MB-231, MDA-MB-361, T47D) and cervical (HeLa, SiHa, C33A) cancer cell lines (Table 1). Estrone derivatives 13 and 14 exhibited antiproliferative action similar to that of reference agent cisplatin in terms of potency, while estrone azide 17 proved to be ineffective. Both artemisininderived compounds $\mathbf{6}$ and 7 elicited growth inhibitory effects comparable to cisplatin with exception for $\mathrm{SiHa}$ cell line, which was not sensitive toward them. All of the synthesized hybrids 812 exhibited substantially pronounced antiproliferative action on breast cancer cells. The most potent hybrid 12 displayed submicromolar $\mathrm{EC}_{50}$ values $(0.18-0.93 \mu \mathrm{M})$ indicating an outstanding increase in the efficacy when compared with the actions of the building elements of the molecule. In the case of cervical cell lines, the actions of the precursors were modest and the increase in the anticancer potency were less dynamic, though compound 9 was remarkable on all utilized cells, and hybrid 12 exhibited promising action on C33A cell line.

Conclusion. In conclusion, several estradiol/estrone derivatives could be coupled to artemisinin for the first time, thereby forming five novel artemisinin-estrogen hybrids 8-12. These were investigated for their in vitro biological activity against malaria parasites (Plasmodium falciparum 3D7), human cytomegalovirus (HCMV), and a selection of human breast and cervical cancer cell lines. All synthesized hybrids exhibited a strong antimalarial effect with $\mathrm{EC}_{50}$ values in the nanomolar range $(3.8-128.8 \mathrm{nM})$. The most active hybrid in terms of antimalarial efficacy, compound 8 , was about two times more active than its parent compound artesunic acid $(7)\left(\mathrm{EC}_{50}=8.9\right.$ $\mathrm{nM})$ as well as the standard drug chloroquine $(9.8 \mathrm{nM})$ and was therefore comparable to the clinically used dihydroartemisinin (6) $\left(\mathrm{EC}_{50}=2.4 \mathrm{nM}\right)$. Furthermore, hybrids 9-12 exhibited high antiviral activity $\left(\mathrm{EC}_{50}=0.22-0.38 \mu \mathrm{M}\right)$ and thus represent a group of very attractive, novel chemical structures exerting a pronounced anti-HCMV activity mostly in the submicromolar range, which appears even superior to the in vitro efficacy of reference drug ganciclovir. Besides the antimicrobial properties of the prepared agents, they exhibited a pronounced growth inhibitory action against a panel of human cancer cells. $\mathrm{EC}_{50}$ values of the hybrids were lower by orders of magnitude when compared with those of the building blocks. Based on the results of the presented antiproliferative assays, hybrid molecules designed and synthesized from artemisinin and estrone elements can be regarded as potential lead molecules for development of innovative anticancer agents. All in all, a relatively low level of effort in chemical synthesis was sufficient to generate very promising pharmacological candidate compounds, which once again highlights the attractiveness of the hybridization concept. We like to stress that this concept possesses a broad translational potential and might be useful for a number of future drug and biomedical developments. 


\section{ASSOCIATED CONTENT}

\section{S Supporting Information}

The Supporting Information is available free of charge on the ACS Publications website at DOI: 10.1021/acsmedchemlett.8b00381.

Experimental conditions and procedures as well as spectral data for precursors $13,15,16,18 a / b, 19$, and 20 and target compounds 8-12; recorded spectra of target compounds; details of cell lines and reagents as well as cell viability assay for biological evaluation (PDF); SMILES data (XLSX)

\section{AUTHOR INFORMATION}

\section{Corresponding Author}

*Fax: (+) 49913185 22865. E-mail: svetlana.tsogoeva@fau.de. ORCID

Svetlana B. Tsogoeva: 0000-0003-4845-0951

Notes

The authors declare no competing financial interest.

\section{ACKNOWLEDGMENTS}

S.B.T. and M.M. are grateful to the Deutsche Forschungsgemeinschaft (DFG) for generous funding by grants TS 87/16-3; MA 1289/7-3 and to the Interdisciplinary Center for Molecular Materials (ICMM), the Graduate School Molecular Science (GSMS), as well as Emerging Fields Initiative (EFI) "Chemistry in Live Cells" supported by Friedrich-Alexander-Universität Erlangen-Nürnberg for research funding. Financial support by the National Research, Development and Innovation OfficeNKFIH through project GINOP-2.3.2.-15-2016-00038 (Hungary) is gratefully acknowledged. Furthermore, the authors are grateful for financial support from OTKA K113150 and K109293. The work of A.K. was supported by a Ph.D. Fellowship of the Talentum Fund of Richter Gedeon Plc. R.M. was supported by a János Bolyai Research Scholarship of the Hungarian Academy of Sciences.

\section{DEDICATION}

This paper is dedicated to Professor Youyou Tu.

\section{ABBREVIATIONS}

DCC, N,N'-dicyclohexylcarbodiimide; DCE, 1,2-dichloroethane; DHA, dihydroartemisinin; DMAP, 4-(dimethylamino)pyridine; EDCI, $\mathrm{N}$-(3-dimethylaminopropyl)- $\mathrm{N}^{\prime}$-ethylcarbodiimide; GFP, green fluorescent protein; HCMV, human cytomegalovirus; HFFs, human foreskin fibroblasts.

\section{REFERENCES}

(1) Arenas-González, A.; Mendez-Delgado, L. A.; Merino-Montiel, P.; Padrón, J. M.; Montiel-Smith, S.; Vega-Báez, J. L.; Meza- Reyes, S. Synthesis of monomeric and dimeric steroids containing $[1,2,4]$ triazolo[1,5-a]pyrimidines. Steroids 2016, 116, 13.

(2) Alsayari, A.; Kopel, L.; Ahmed, M. S.; Pay, A.; Carlson, T.; Halaweish, F. T. Design, synthesis, and biological evaluation of steroidal analogs as estrogenic/anti-estrogenic agents. Steroids 2017, 118, 32.

(3) Khan, M. O. F.; Lee, H. J. Synthesis and Pharmacology of Antiinflammatory Steroidal Antedrugs. Chem. Rev. 2008, 108, 5131.

(4) Biju, P.; Bitar, R.; Lim, Y.-H.; Wang, Y.; Berlin, M.; Aslanian, R.; McCormick, K. Synthesis of novel anti-inflammatory steroidal macrocycles using ring closing metathesis reaction. Tetrahedron Lett. 2015, 56, 636.

(5) Krieg, R.; Jortzik, E.; Goetz, A. A.; Blandin, S.; Wittlin, S.; Elhabiri, M.; Rahbari, M.; Nuryyeva, S.; Voigt, K.; Dahse, H. M.; Brakhage, A.;
Beckmann, S.; Quack, T.; Grevelding, C. G.; Pinkerton, A. B.; Schonecker, B.; Burrows, J.; Davioud-Charvet, E.; Rahlfs, S.; Becker, K. Arylmethylamino steroids as antiparasitic agents. Nat. Commun. 2017, 8, 14478.

(6) Nadaraia, N. S.; Onashvili, E. O.; Kakhabrishvili, M. L.; Barbakadze, N. N.; Sylla, B.; Pichette, A. Synthesis and Antiviral Activity of Several NContaining $5 \alpha$-STEROIDS. Chem. Nat. Compd. 2016, 52, 853.

(7) Zhao, J. L.; Zhang, M.; Liu, J. M.; Tan, Z.; Chen, R. D.; Xie, K. B.; Dai, J. G. Bioactive steroids and sorbicillinoids isolated from the endophytic fungus Trichoderma sp. Xy24. J. Asian Nat. Prod. Res. 2017, $19,1028$.

(8) Deroo, B. J.; Korach, K. S. Estrogen receptors and human disease. J. Clin. Invest. 2006, 116, 561.

(9) Jones, S. E. Fulvestrant: an estrogen receptor antagonist that downregulates the estrogen receptor. Semin. Oncol. 2003, 30, 14.

(10) Fotsis, T.; Zhang, Y.; Pepper, M. S.; Adlercreutz, H.; Montesano, R.; Nawroth, P. P.; Schweigerer, L. The endogenous oestrogen metabolite 2-methoxyoestradiol inhibits angiogenesis and suppresses tumour growth. Nature 1994, 368, 237.

(11) Tevaarwerk, A.J.; Holen, K. D.; Alberti, D. B.; Sidor, C.; Arnott, J.; Quon, C.; Wilding, G.; Liu, G. Phase I Trial of 2-Methoxyestradiol $\left(2 \mathrm{ME} 2\right.$, Panzem $\left.{ }^{\circledR}\right)$ NanoCrystal ${ }^{\circledR}$ Dispersion $\left(\mathrm{NCD}^{\circledR}\right)$ in Advanced Solid Malignancies. Clin. Cancer Res. 2009, 15, 1460.

(12) Fukui, M.; Zhu, B. T. Mechanism of 2-methoxyestradiol-induced apoptosis and growth arrest in human breast cancer cells. Mol. Carcinog. 2009, 48, 66 .

(13) Kulke, M. H.; Chan, J. A.; Meyerhardt, J. A.; Zhu, A. X.; Abrams, T. A.; Blaszkowsky, L. S.; Regan, E.; Sidor, C.; Fuchs, C. S. A prospective phase II study of 2-methoxyestradiol administered in combination with bevacizumab in patients with metastatic carcinoid tumors. Cancer Chemother. Pharmacol. 2011, 68, 293.

(14) Bruce, J. Y.; Eickhoff, J.; Pili, R.; Logan, T.; Carducci, M.; Arnott, J.; Treston, A.; Wilding, G.; Liu, G. A phase II study of 2methoxyestradiol nanocrystal colloidal dispersion alone and in combination with sunitinib malate in patients with metastatic renal cell carcinoma progressing on sunitinib malate. Invest. New Drugs 2012, 30, 794 .

(15) Gorska, M.; Kuban-Jankowska, A.; Slawek, J.; Wozniak, M. New Insight into 2-Methoxyestradiol- a Possible Physiological Link between Neurodegeneration and Cancer Cell Death. Curr. Med. Chem. 2016, 23, 1513.

(16) Lakhani, N. J.; Sarkar, M. A.; Venitz, J.; Figg, W. D. 2Methoxyestradiol, a promising anticancer agent. Pharmacotherapy 2003, 23, 165 .

(17) Luc, J. G. Y.; Paulin, R.; Zhao, J. Y.; Freed, D. H.; Michelakis, E. D.; Nagendran, J. 2-Methoxyestradiol: A Hormonal Metabolite Modulates Stimulated T-Cells Function and proliferation. Transplant. Proc. 2015, 47, 2057.

(18) Perez-Sepulveda, A.; España-Perrot, P. P.; Norwitz, E. R.; Illanes, S. E. Metabolic Pathways Involved in 2-Methoxyestradiol Synthesis and Their Role in Preeclampsia. Reprod. Sci. 2013, 20, 1020.

(19) Reiter, C.; Fröhlich, T.; Zeino, M.; Marschall, M.; Bahsi, H.; Leidenberger, M.; Friedrich, O.; Kappes, B.; Hampel, F.; Efferth, T.; Tsogoeva, S. B. New efficient artemisinin derived agents against human leukemia cells, human cytomegalovirus and Plasmodium falciparum: 2nd generation 1,2,4-trioxane-ferrocene hybrids. Eur. J. Med. Chem. 2015, $97,164$.

(20) Fröhlich, T.; Ndreshkjana, B.; Muenzner, J. K.; Reiter, C.; Hofmeister, E.; Mederer, S.; Fatfat, M.; El-Baba, C.; Gali-Muhtasib, H.; Schneider-Stock, R.; Tsogoeva, S. B. Synthesis of Novel Hybrids of Thymoquinone and Artemisinin with High Activity and Selectivity Against Colon Cancer. ChemMedChem 2017, 12, 226.

(21) Held, F. E.; Guryev, A. A.; Fröhlich, T.; Hampel, F.; Kahnt, A.; Hutterer, C.; Steingruber, M.; Bahsi, H.; von Bojničić-Kninski, C.; Mattes, D. S.; Foertsch, T. C.; Nesterov-Mueller, A.; Marschall, M.; Tsogoeva, S. B. Facile access to potent antiviral quinazoline heterocycles with fluorescence properties via merging metal-free domino reactions. Nat. Commun. 2017, 8, 15071. 
(22) Fröhlich, T.; Reiter, C.; Saeed, M. E. M.; Hutterer, C.; Hahn, F.; Leidenberger, M.; Friedrich, O.; Kappes, B.; Marschall, M.; Efferth, T.; Tsogoeva, S. B. Synthesis of Thymoquinone-Artemisinin Hybrids: New Potent Antileukemia, Antiviral and Antimalarial Agents. ACS Med. Chem. Lett. 2018, 9, 534.

(23) Mehta, G.; Singh, V. Hybrid systems through natural product leads: An approach towards new molecular entities. Chem. Soc. Rev. 2002, 31, 324

(24) Tietze, L. F.; Bell, H. P.; Chandrasekhar, S. Natural Product Hybrids as New Leads for Drug Discovery. Angew. Chem., Int. Ed. 2003, 42,3996

(25) Tu, Y. The discovery of artemisinin (qinghaosu) and gifts from Chinese medicine. Nat. Med. 2011, 17, 1217.

(26) Su, X.-z.; Miller, L. H. The discovery of artemisinin and Nobel Prize in Physiology or Medicine. Sci. China: Life Sci. 2015, 58, 1175.

(27) Qinghaosu Antimalarial Coordinating Research Group. Antimalaria studies on Qinghaosu. Chin. Med. J. (Engl. Ed.) 1979, 12, 811816.

(28) Klayman, D. Qinghaosu (artemisinin): an antimalarial drug from China. Science 1985, 228, 1049.

(29) Miller, L. H.; Su, X. Artemisinin: Discovery from the Chinese Herbal Garden. Cell 2011, 146, 855.

(30) Romero, M. R.; Serrano, M. A.; Vallejo, M.; Efferth, T.; Alvarez, M.; Marin, J. J. Antiviral effect of artemisinin from Artemisia annua against a model member of the Flaviviridae family, the bovine viral diarrhoea virus (BVDV). Planta Med. 2006, 72, 1169.

(31) Paeshuyse, J.; Coelmont, L.; Vliegen, I.; Van hemel, J.; Vandenkerckhove, J.; Peys, E.; Sas, B.; De Clercq, E.; Neyts, J. Hemin potentiates the anti-hepatitis $\mathrm{C}$ virus activity of the antimalarial drug artemisinin. Biochem. Biophys. Res. Commun. 2006, 348, 139.

(32) Efferth, T.; Romero, M. R.; Wolf, D. G.; Stamminger, T.; Marin, J. J.; Marschall, M. The antiviral activities of artemisinin and artesunate. Clin. Infect. Dis. 2008, 47, 804.

(33) Parvez, M. K.; Arbab, A. H.; Al-Dosari, M. S.; Al-Rehaily, A. J. Antiviral Natural Products Against Chronic Hepatitis B: Recent Developments. Curr. Pharm. Des. 2016, 22, 286.

(34) Woerdenbag, H. J.; Moskal, T. A.; Pras, N.; Malingre, T. M.; elFeraly, F. S.; Kampinga, H. H.; Konings, A. W. Cytotoxicity of artemisinin-related endoperoxides to Ehrlich ascites tumor cells. J. Nat. Prod. 1993, 56, 849.

(35) Singh, N. P.; Lai, H. C. Artemisinin induces apoptosis in human cancer cells. Anticancer Res. 2004, 24, 2277-2280.

(36) Efferth, T. Molecular pharmacology and pharmacogenomics of artemisinin and its derivatives in cancer cells. Curr. Drug Targets 2006, 7, 407.

(37) Lai, H. C.; Singh, N. P.; Sasaki, T. Development of artemisinin compounds for cancer treatment. Invest. New Drugs 2013, 31, 230.

(38) Li, Z.; Li, Q.; Wu, J.; Wang, M.; Yu, J. Artemisinin and Its Derivatives as a Repurposing Anticancer Agent: What Else Do We Need to Do? Molecules 2016, 21, 1331.

(39) Crespo-Ortiz, M. P.; Wei, M. Q. Antitumor Activity of Artemisinin and Its Derivatives: From a Well-Known Antimalarial Agent to a Potential Anticancer Drug. J. Biomed. Biotechnol. 2012, 2012, 1 .

(40) Sun, H.; Meng, X.; Han, J.; Zhang, Z.; Wang, B.; Bai, X.; Zhang, X. Anti-cancer activity of DHA on gastric cancer - An in vitro and in vivo study. Tumor Biol. 2013, 34, 3791.

(41) Xu, G.; Zou, W.-Q.; Du, S.-J.; Wu, M.-J.; Xiang, T.-X.; Luo, Z.-G. Mechanism of dihydroartemisinin-induced apoptosis in prostate cancer PC3 cells: An iTRAQ-based proteomic analysis. Life Sci. 2016, 157, 1.

(42) Looareesuwan, S.; Wilairatana, P.; Vanijanonta, S.; Pitisuttithum, P.; Ratanapong, Y.; Andrial, M. Monotherapy with sodium artesunate for uncomplicated falciparum malaria in Thailand: a comparison of 5and 7-day regimens. Acta Trop. 1997, 67, 197.

(43) Kaptein, S. J. F.; Efferth, T.; Leis, M.; Rechter, S.; Auerochs, S.; Kalmer, M.; Bruggeman, C. A.; Vink, C.; Stamminger, T.; Marschall, M. The anti-malaria drug artesunate inhibits replication of cytomegalovirus in vitro and in vivo. Antiviral Res. 2006, 69, 60.
(44) Michaelis, M.; Kleinschmidt, M. C.; Barth, S.; Rothweiler, F.; Geiler, J.; Breitling, R.; Mayer, B.; Deubzer, H.; Witt, O.; Kreuter, J.; Doerr, H. W.; Cinatl, J.; Cinatl, J., Jr. Anti-cancer effects of artesunate in a panel of chemoresistant neuroblastoma cell lines. Biochem. Pharmacol. 2010, 79, 130 .

(45) Zhou, X.; Sun, W. J.; Wang, W. M.; Chen, K.; Zheng, J. H.; Lu, M. D.; Li, P. H.; Zheng, Z. Q. Artesunate inhibits the growth of gastric cancer cells through the mechanism of promoting oncosis both in vitro and in vivo. Anti-Cancer Drugs 2013, 24, 920.

(46) von Hagens, C.; Walter-Sack, I.; Goeckenjan, M.; Osburg, J.; Storch-Hagenlocher, B.; Sertel, S.; Elsässer, M.; Remppis, B. A.; Edler, L.; Munzinger, J.; Efferth, T.; Schneeweiss, A.; Strowitzki, T. Prospective open uncontrolled phase I study to define a well-tolerated dose of oral artesunate as add-on therapy in patients with metastatic breast cancer (ARTIC M33/2). Breast Cancer Res. Treat. 2017, 164, 359.

(47) Stocks, P. A.; Bray, P. G.; Barton, V. E.; Al-Helal, M.; Jones, M.; Araujo, N. C.; Gibbons, P.; Ward, S. A.; Hughes, R. H.; Biagini, G. A.; Davies, J.; Amewu, R.; Mercer, A. E.; Ellis, G.; O’Neill, P. M. Evidence for a Common Non-Heme Chelatable-Iron-Dependent Activation Mechanism for Semisynthetic and Synthetic Endoperoxide Antimalarial Drugs. Angew. Chem., Int. Ed. 2007, 46, 6278.

(48) Posner, G. H.; Ploypradith, P.; Parker, M. H.; O’Dowd, H.; Wou, S.-H.; Northrop, J.; Krasavin, M.; Dolan, P.; Kensler, T. W.; Xie, S.; Shapiro, T. A. Antimalarial, antiproliferative, and antitumor activities of artemisinin-derived, chemically robust, trioxane dimers. J. Med. Chem. $1999,42,4275$.

(49) Schönecker, B.; Ponsold, K. Steroide. XXX. Synthesen vicinaler Steroid-Azidoketone. J. Prakt. Chem. 1971, 313, 817.

(50) Schönecker, B.; Ponsold, K. Steroide-XL. Tetrahedron 1975, 31, 1113.

(51) Becker, K.; Krieg, R.; Schönecker, B. Derivate von steroidbenzylaminen mit antiparasitärer, antibakterieller, antimykotischer und/oder antiviraler wirkung. DE 102010047714 A1, 2012.

(52) Bora, P. P.; Baruah, N.; Bez, G.; Barua, N. C. New Method for the Synthesis of Ether Derivatives of Artemisinin. Synth. Commun. 2012, 42, 1218.

(53) Fröhlich, T.; Reiter, C.; Ibrahim, M. M.; Beutel, J.; Hutterer, C.; Zeitträger, I.; Bahsi, H.; Leidenberger, M.; Friedrich, O.; Kappes, B.; Efferth, T.; Marschall, M.; Tsogoeva, S. B. Synthesis of Novel Hybrids of Quinazoline and Artemisinin with High Activities against Plasmodium falciparum, Human Cytomegalovirus, and Leukemia Cells. ACS Omega 2017, 2, 2422.

(54) Fröhlich, T.; Çapcı Karagöz, A.; Reiter, C.; Tsogoeva, S. B. Artemisinin-Derived Dimers: Potent Antimalarial and Anticancer Agents. J. Med. Chem. 2016, 59, 7360-7388.

(55) Marschall, M.; Freitag, M.; Weiler, S.; Sorg, G.; Stamminger, T. Recombinant Green Fluorescent Protein-Expressing Human Cytomegalovirus as a Tool for Screening Antiviral Agents. Antimicrob. Agents Chemother. 2000, 44, 1588-1597.

(56) Marschall, M.; Niemann, I.; Kosulin, K.; Bootz, A.; Wagner, S.; Dobner, T.; Herz, T.; Kramer, B.; Leban, J.; Vitt, D.; Stamminger, T.; Hutterer, C.; Strobl, S. Assessment of drug candidates for broadspectrum antiviral therapy targeting cellular pyrimidine biosynthesis. Antiviral Res. 2013, 100, 640.

(57) Hutterer, C.; Eickhoff, J.; Milbradt, J.; Korn, K.; Zeitträger, I.; Bahsi, H.; Wagner, S.; Zischinsky, G.; Wolf, A.; Degenhart, C.; Unger, A.; Baumann, M.; Klebl, B.; Marschall, M. A novel CDK7 inhibitor of the Pyrazolotriazine class exerts broad-spectrum antiviral activity at nanomolar concentrations. Antimicrob. Agents Chemother. 2015, 59, 2062.

(58) Hutterer, C.; Niemann, I.; Milbradt, J.; Fröhlich, T.; Reiter, C.; Kadioglu, O.; Bahsi, H.; Zeitträger, I.; Wagner, S.; Einsiedel, J.; Gmeiner, P.; Vogel, N.; Wandinger, S.; Godl, K.; Stamminger, T.; Efferth, T.; Tsogoeva, S. B.; Marschall, M. The broad-spectrum antiinfective drug artesunate interferes with the canonical nuclear factor kappa B (NFkappaB) pathway by targeting RelA/p65. Antiviral Res. 2015, 124, 101. 